\title{
Pengaruh Mekanisme Corporate Governance, Bonus Plans, Debt coveant dan Ukuran Perusahaan Terhadap Manajemen Laba
}

\author{
Marfuah * \\ Himawan Yogatama **
}

\begin{abstract}
The purpose of this study was to examine the effect of corporaie governance mechanisms, bonus plans, debt covenants and firm size on earnings management. Corporate governance mechanisms in this study was measured using four variables, namely the concentration of ownership, independent commissioners, audit committee and auditor reputation. 93 samples are selected by purposip sampling the observation period of 2009 through 2011.

Four corporate governance variables thought to have a negative impact on earnings management, while the variable bonus plans, debt covenants and firm size has a positive influence on earnings management. Based on regression analysis found that the two corporate governance variables, namely the concentration of ownership and auditor reputation as predicted significant negative effect on earnings management. This indicates that the higher the level of concentration of ownership and auditor reputation, then the earnings management measures will decrease. While testing the variable audit committee and independent commissioners found results inconsistent with previous predictions. The audit committee has a significant positive effect on earnings management, while independent dire commissioners has no significant negative impact on earnings management.

The test results of the other three variables, namely bonus plans, debt covenants and the size of the company shows that the only variable bonus plans that have a significant positive effect on earnings management. This indicates that earnings management tends to occur in companies that have a bonus scheme, because managers tend to perform actions that manage earnings to maximize bonuses they receive.
\end{abstract}

Keywords: earnings management, corporate governance, bonus plans, debt covenant

Dosen tetap FE UII

"*Mahasiswa Jurusan Akuntansi FE UII 


\section{Pendahuluan}

Informasi laba sebagai bagian dari laporan keuangan, sering menjadi target rekayasa melalui tindakan oportunis manajemen untuk memaksimumkan kepuasannya, tetapi dapat merugikan pemegang saham atau investor. Tindakan oportunis tersebut dilakukan dengan cara memilih kebijakan akuntansi tertentu, sehingga laba perusahaan dapat diatur, dinaikkan atau diturunkan sesuai dengan keinginannya. Perilaku manajemen untuk mengatur laba sesuai dengan keinginannya tersebut dikenal dengan istilah manajemen laba (earnings management).

Manajemen laba timbul sebagai dampak persoalan keagenan yaitu adanya ketidakselarasan kepentingan antara pemilik dan manajemen (Beneish, 2001). Menurut teori keagenan, untuk mengatasi masalah tersebut adalah dengan tata kelola perusahaan yang baik (good corporate governance). Corporate Governance merupakan suatu mekanisme yang digunakan pemegang saham dan kreditor perusahaan untuk mengendalikan tindakan manajer (Dallas, 2004). Mekanisme tersebut dapat berupa mekanisme internal yaitu; struktur kepemilikan, struktur dewan komisaris, konpensasi eksekutif, struktur bisnis multidivisi, dan mekanisme eksternal yaitu; pengendalian oleh pasar, kepemilikan institusional, dan pelaksanaan audit oleh auditor eksternal (Babic, 2001).

Tindakan manajemen laba dapat merugikan pemegang saham, karena informasi laba yang disajikan dapat menyebabkan keputusan investasi yang salah. Oleh karena itu, perlu diketahui faktor-faktor yang mempengaruhi manajemen laba. Perilaku manajemen laba dapat dijelaskan melalui Positive Accounting Theory (PAT) dan Agency Theory. Tiga hipotesis PAT yang dapat dijadikan dasar pemahaman tindakan 
manajemen laba yang dirumuskan Watts and Zimmerman (1986:257.-262) yang ditegaskan kembali oleh Scott (2003:276-278), yaitu pertama the bonus plan hypothesis, hipotesis ini menyatakan bahwa manajer pada perusahaan dengan bonus plan cenderung untuk menggunakan metode akuntansi yang akan meningkatkan income saat ini. Perusahaan yang memiliki rencana pemberian bonus, manajer perusahaan akan lebih memilih metode akuntansi yang dapat menggeser laba dari masa depan ke masa kini, sehingga dapat menaikkan laba saat ini. Hal ini dikarenakan manajer lebih menyukai pemberian upah yang lebih tinggi untuk masa kini. Dalam kontrak bonus dikenal dua istilah yaitu bogey (tingkat laba terendah untuk mendapatkan bonus) dan cap (tingkat laba tertinggi). Jika laba berada di bawah bogey, maka tidak ada bonus yang diperoleh manajer sedangkan jika laba berada di atas cap, manajer tidak akan mendapat bonus tambahan. Jika laba bersih berada di bawah bogey, manajer cenderung memperkecil laba dengan harapan memperoleh bonus lebih besar pada periode berikutnya, demikian pula jika laba berada di atas cap. Jadi hanya jika laba bersih berada di antara bogey dan cap, manajer akan berusaha menaikkan laba bersih perusahaan.

Kedua, the debt covenant hypothesis, hipotesis ini menyebutkan bahwwa pada perusahaan yang mempunyai rasio debt to equity besar maka manajer perusahaan tersebut cenderung menggunakan metode akuntansi yang akan meningkatkan pendapatan maupun laba. Ketiga, the political cost hypothesis, hipotesis ini menyatakan bahwa pada perusahaan yang besar yang memiliki biaya politik tinggi, manajer akan lebih memilih metode akuntansi yang menangguhkan laba yang dilaporkan dari periode sekarang ke periode masa mendatang sehingga dapat memperkecili laba yang dilaporkan. Biaya politik muncul dikarenakan profitab̆ilitas 
perusahaan yang tinggi dapat menarik perhatian media dan konsumen. Berdasarkan uraian diatas, maka tujuan penelitian ini adalah untuk menguji secara empiris pengaruh mekanisme corporate governance, bonus plans, debt covenant dan ukuran perusahaan terhadap manajemen laba.

\section{Penelitian Terdahulu dan Perumusan Hipotesis}

\section{Penelitian terdahulu}

Penelitian yang mengkaji faktor-faktor yang mempengaruhi manajemen laba telah banyak dilakukan. Luhgiatno (2008) menemukan bahwa untuk mencegah tindakan manajemen Laba dapat dilakukan dengan mengimplementasikan mekanisme corporate governance. Penelitian Wedari (2004) dan Boediono (2005) menunjukkan bahwa komite audit berpengaruh positif terhadap manajemen laba. Hal yang sama juga ditemukan dalam penelitian Nasution dan Setiawan (2007) yang menunjukkan bahwa komite audit berpengaruh positif terhadap manajemen laba.

Palestin (2006) menemukan bahwa struktur kepemilikan dan proporsi dewan komisaris berpengaruh negatif terhadap manajemen laba, sedangkan bonus plans berpengaruh positif terhadap manajemen laba. Temuan Nuryaman (2005) menunjukkan bahwa tiga variabel yaitu konsentrasi kepemilikan, ukuran perusahaan dan mekanisme corporate governance berpengaruh negatif terhadap manajemen laba.

Widyaningdyah (2001) menemukan leverage (debt covenant) berpengaruh positif terhadap earnings management. Hal ini berarti earnings management berkaitan dengan sumber dana eksternal 
khususnya utang yang digunakan untuk membiayai kelangsủngan perusahaan. Hal tersebut diperkuat dengan temuan Nurul dan Baridwan (2007) yang menunjukkan bahwa debt covenant berpengaruh positif terhadap manajemen laba.

Perusahaan yang berukuran besar memiliki basis pemegang kepentingan yang lebih luas, sehingga berbagai kebijakan perusahaan besar akan berdampak lebih besar terhadap kepentingan publik dibandingkan dengan perusahaan kecil. Bagi investor, kebijakan perusahaan akan berimplikasi terhadap prospek cash flow dimasa yang akan datang. Sedangkan bagi regulator (pemerintah) akan berdampak terhadap besarnya pajak yang akan diterima, serta efektifitas peran pemberian perlindungan terhadap masyarakat secara umum.

Terdapat dua pandangan tentang bentuk hubungan ukuran perusahaan terhadap manajemen laba. Pandangan pertama menyatakan bahwa ukuran perusahaan memiliki hubungan positif dengan manajemen laba, karena perusahaan besar memiliki aktivitas operasional yang lebih kompleks díbandingkan perusahaan kecil, sehingga lebih memungkinkan untuk melakukan manajemen laba. Moses (1997) mengemukakan bahwa perusahaan - perusahaan yang lebih besar memiliki dorongan yang lebih besar untuk melakukan perataan laba (salah satu bentuk manajemen laba) dibandingkan dengan perusahaan kecil, karena memiliki biaya politik lebih besar. Biaya politik muncul dikarenkan profitabilitas perusahaan yang tinggi dapat menarik perhatian media dan konsumen.

Pandangan kedua menyatakan bahwa ukuran perusahaan memiliki hubungan negatif dengan manajemen laba. Penelitian di Amerika Serikat yang dilakukan oleh Marrakchi (2001) dengan menggunakan data sampel 
perusahaan industri tahun 1996 menemukan bahwa ukuran perusahaan memiliki hubungan negatif dengan manajemen laba. Perusahaan yang lebih besar kurang memiliki dorongan untuk melakukan manajemen laba dibandingkan perusahaan-perusahaan kecil, karena perusahaan besar dipandang lebih kritis oleh pemegang saham dan pihak luar. Perusahaan besar memiliki basis investor yang lebih besar, sehingga mendapat tekanan yang lebih kuat untuk menyajikan pelaporan keuangan yang kredible.

Komite audit adalah komite yang dibentuk oleh dewan komisaris untuk melakukan tugas pengawasan pengelolaan perusahaan. Komite audit mempunyai tanggung jawab utama untuk membantu dewan komisaris dalam menjalankan tanggung jawabnya terutama dengan masalah yang berhubungan dengan kebijakan akuntansi perusahaan, pengawasan internal, dan sistem pelaporan keuangan. Komite audit juga yang bertanggung jawab untuk mengawasi laporan keuangan, mengawasi audit eksternal, dan mengamati sistem pengendalian internal (termasuk audit internal) dapat mengurangi sifat opportunistic manajemen yang melakukan manajemen laba (earnings management) dengan cara mengawasi laporan keuangan dan melakukan pengawasan pada audit eksternal (Hamongan dan Mas'ud, 2006).

Reputasi auditor sangat menentukan kredibilitas laporan keuangan. Independensi dan kualitas auditor akan berdampak terhadap pendeteksian manajemen laba. Reputasi auditor yang baik merupakan salah satu faktor yang dapat mengurangi terjadinya tindakan manajemen laba, oleh karena dengan adanya auditor yang mempunyai reputasi kurang baik maka 
manajer berpeluang untuk melakukan manajemen laba (Widyaningdyah, 2001).

Bonus plan hypothesis merupakan salah satu motif pemilihan suatu metode akuntansi tidak terlepas dari positif accounting theory. Hipotesis ini menyatakan bahwa manajer perusahaan dengan rencana bonus lebih menyukai metode akuntansi yang meningkatkan laba periode berjalan. Jika perusahaan memiliki Bonus Plans, maka manajer akan cenderung míelakukan tindakan yang mengatur laba bersih untuk dapat memaksimalkan bonus yang mereka terima (Palestin, 2006).

Debt-covenant hypothesis menyatakan bahwa jika semua hal lain tetap sama, semakin dekat perusahaan dengan pelanggaran perjanjian utang yang berbasis akuntansi, lebih mungkin manajer perusahaan untuk memilih prosedur akuntansi yang memindahkan laba yang dilaporkan dari perioda masa datang ke perioda saat ini. Jadi sangat dimungkinkan manajer perusahaan mempengaruhi angka-angka akuntansi pada laporan keuangan. Angka-angka akuntansi dapat dipengaruhi dengan melakukan manajemen laba ( Nurul dan Baridwan, 2005).

Manajemen pada perusahaan yang berskala besar dan industri strategis yang melibatkan hajat hidup orang banyak memiliki biaya politis yang besar cenderung untuk melakukan manajemen laba dengan cara menurunkan laba. (Scoot, 2003 dalam Luhgiatno, 2008). Karena biaya politik yang tinggi dapat menarik perhatian media dan konsumen (Watts dan Zimmerman, 1986 dalam Halim,dkk 2005). 


\section{Perumusan Hipotesis Penelitian}

Berdasarkan landasan teori di atas, penelitian ini mengkaji 7 (tujuh) variable yang diduga berpengaruh terhadap manajemen laba. Hubungan antara ke tujuh variabel independen yang diduga berpengaruh terhadap manajemen laba digambarkan dalam kerangka penelitian berikut:

\section{Gambar 1}

Kerangka Penelitian

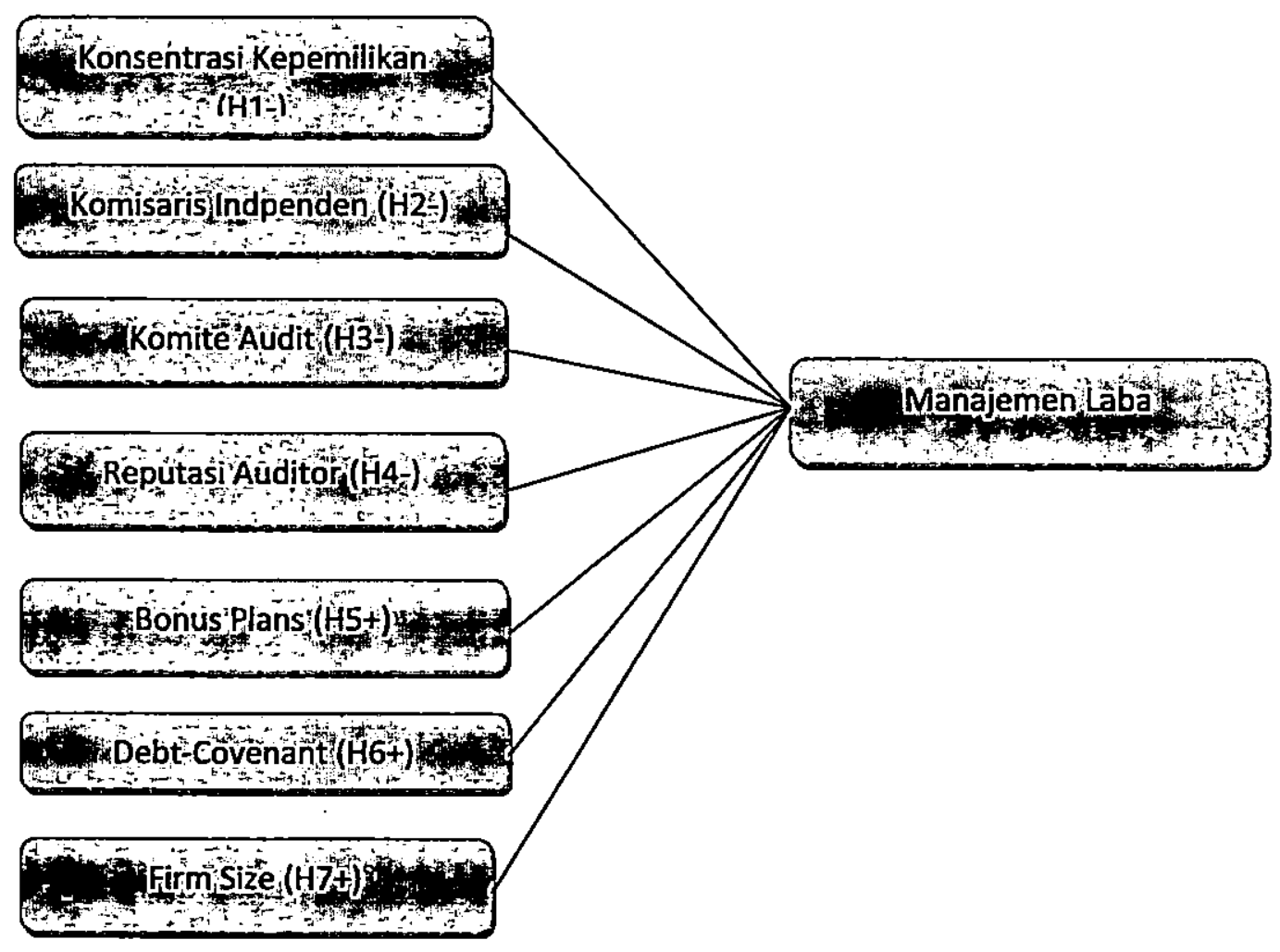

\section{Pengaruh Konsentrasi Kepemilikan terhadap Manajemen Laba}

Kepemilikan saham dikatakan terkonsentrasi jika sebagian besar saham dimiliki oleh sebagian kecil individu atau kelompok, sehingga pemegang saham tersebut memiliki jumlah saham yang relatif dominan 
Marfuah \& Himawan Yogatama, Pengaruh Mekanisme

dibandingkan dengan lainnya. Kepemilikan saham dikatakan meny̆ebar, jika kepemilikan saham menyebar secara relatif merata ke publik, "ijdak ada yang memiliki saham dalam-jumlah sangat besar dibandingkan dengan lainnya (Dallas, 2004).

Konsentrasi kepemilikan dapat menjadi mekanisme internal pendisiplinan manajemen, sebagai salah satu mekanisme yang dapat digunakan untuk meningkatkan efektivitas monitoring, karena dengan kepemilikan yang besar menjadikan pemegang saham memiliki akses informasi yang cukup signifikan untuk mengimbangi keuntungan informasional yang dimiliki manajemen. Jika ini dapat diwujudkan maka tindakan moral hazard manajemen berupa manajemen laba dapat dikurangi (Hubert dan Langhe, 2002).

Di negara-negara dengan derajat perlindungan terhadap investor rendah (seperti halnya Indonesia), pemegang saham merasa khawatir akan kemungkinan berbedanya pendapatan yang diperoleh dengan yang diekspektasikan. Akibatnya, mereka memperbesar persentase kepemilikan atas perusahaan sebagai salah satu cara untuk melindungi diri. Mereka dapat mengendalikan perusahaan melalui voting power, atau representasi mereka di manajemen sehingga hak-hak mereka terlindungi (La Porta dan Silanez 1999).

Musnadi (2006) melakukan penelitian tentang struktur kepemilikan sebagai mekanisme corporate govenrnance, serta dampaknya terhadap kinerja keuangan perusahaan, dengan menggunakan emiten non financial yang berkapitalisasi menengah besar yang terdaftar di Bursa Efek Indonesia. Hasilnya menunjukan bahwa kepemilikan terkonsentrasi terbesar memiliki pengaruh negatif terhadap kinerja 
keuangan perusahaan. Hasil ini bermakna bahwa kepemilikan saham terkonsentrasi dapat berperan sebagai mekanisme corporate governance dalam mengurangi persoalan keagenan, sebab konsentrasi kepemilikan dapat menjadikan pemegang saham pada posisi yang kuat untuk dapat mengendalikan manajemen secara efektif, sehingga mendorong manajemen bertindak sesuai dengan kepentingan pemegang saham.

H1: Konsentrasi kepemilikan berpengaruh negatif terhadap manajemen laba

\section{Pengaruh Komisaris Independen terhadap Manajemen Laba}

Kao dan Chen (2004) melakukan penelitian di Taiwan. Mereka mengemukakan bahwa outside directors lebih independen terhadap manajemen dibandingkan dengan inside directors, sehingga lebih efektif dalam melaksanakan fungsi pengawasan terhadap manajemen. Hasil penelitiannya menunjukkan bahwa semakin besar proporsi outside directors semakin berkurang earnings management. Hasil penelitian Chen et.al (2005a) di China, menunjukkan bahwa proporsi outside directors, frekuensi pertemuan anggota dewan dalam setahun, lamanya top of director menduduki posisi tersebut, berpengaruh terhadap kecurangan dalam laporan keuangan. Sarkar dkk (2006) melakukan penelitian di India, hasil temuannya menunjukkan bahwa keberadaan board of director independence dapat membatasi earnings management, jika Board of director tersebut memiliki kompetensi dan tidak sibuk.

Penelitian tentang pengaruh dewan komisaris terhadap manajemen telah dilakukan di Indonesia, antara lain Budiwitjaksono (2005) menyimpulkan bahwa komposisi Dewan Komisaris berpengaruh yang sangat lemah terhadap manajemen laba. Sementara Veronica dan 
Siddharta (2005) menyimpulkan bahwa komposisi dewan komisarištidak terbukti memiliki pengaruh negatif signifikan terhadap manajemënlaba. Kedua penelitian tersebut dilakukan saat aturan dari BEI tentang keharusan memiliki komisaris independen masih relatif baru, sehingga diduga emiten belum melaksanakannya secara optimal. Salah satu butir Keputusan Direksi PT.Bursa Efek Jakarta No.Kep-315/BEJ/06-2000, bahwa emiten sekurang-kurangnya harus memiliki 30\% Komisaris independen dari seluruh jumlah anggota Komisaris (www.Bapepam.com, 2005).

H2: Komisaris Independen berpengaruh negatif terhadap Manajemen Laba

\section{Pengaruh Komite Audit terhadap Manajemen Laba}

Komite audit adalah komite yang dibentuk oleh dewan komisaris untuk melakukan tugas pengawasan pengelolaan perusahaan. Komite audit mempunyai tanggung jawab utama untuk membantu dewan komisaris dalam menjalankan tanggung jawabnya terutama dengan masalah yang berhubungan dengan kebijakan akuntansi perusahaan, pengawasan internal, dan sistem pelaporan keuangan. Komite audit juga bertanggung jawab untuk mengawasi laporan keuangan, mengawasi audit eksternal, dan mengamati sistem pengendalian internal (termasuk audit internal) sehingga keberadaan komite audit diharapkan dapat mengurangi sifat opportunistic manajemen untuk melakukan manajemen laba (Hamongan dan Mas'ud, 2006). Berdasarkan penjelasan diatas, maka hipotesis dapat dirumuskan sebagai berikut:

H3: Komite audit berpengaruh negatif terhadap manajemen laba 


\section{Pengaruh Reputasi Auditor terhadap Manajemen Laba}

Reputasi auditor sangat menentukan kredibilitas laporan keuangan. Independensi dan kualitas auditor akan berdampak terhadap pendeteksian manajemen laba. Reputasi auditor yang baik merupakan salah satu faktor yang dapat mengurangi terjadinya tindakan manajemen laba, sebaliknya auditor yang mempunyai reputasi kurang baik maka manajer berpeluang untuk melakukan manajemen laba (Widyaningdyah, 2001). Berdasarkan penjelasan di atas, maka hipotesis dapat dirumuskan sebagai berikut:

H4: Reputasi auditor berpengaruh negatif terhadap manajemen laba.

\section{Pengaruh Bonus Plans terhadap Manajemen Laba}

Bonus plans hypothesis merupakan salah satu motif pemilihan suatu metode akuntansi. Hipotesis ini menyatakan bahwa manajer perusahaan dengan rencana bonus, lebih menyukai metode akuntansi yang meningkatkan laba periode berjalan. Jika perusahaan memiliki bonus plans, maka manajer akan cenderung melakukan tindakan yang mengatur laba bersih untuk dapat memaksimalkan bonus yang mereka terima (Palestin, 2006). Berdasarkan penjelasan di atas, maka hipotesis dirumuskan sebagai berikut:

H5: Bonus plans berpengaruh positif terhadap manajemen laba.

\section{Pengaruh Debt Covenant dan Manajemen Laba}

Debt-covenant hypothesis menyatakan bahwa jika semua hal lain tetap konstan, maka semakin dekat perusahaan dengan pelanggaran perjanjian utang yang berbasis akuntansi lebih memungkinkan bagi 
manajer perusahaan untuk memilih prosedur akuntansi...yang memindahkan laba yang dilaporkan dari perioda masa datang ke perioda saạt ini. Jadi sangat dimungkinkan manajer perusahaan mempengaruhi angka-angka akuntansi pada laporan keuangan. Angka-angka akuntansi dapat dipengaruhi dengan melakukan manajemen laba (Nurul dan Baridwan, 2005). Berdasarkan penjelasan di atas, maka hipotesis dapat dirumuskan sebagai berikut:

H6: Debt covenant berpengaruh positif terhadap manajemen laba

\section{Pengaruh Ukuran Perusahaan terhadap Manajemen Laba}

Perusahaan besar memiliki aktivitas operasional yang lebih kompleks dibandingkan perusahaan kecil, sehingga lebih memungkinkan urtuk melakukan manajemen laba. Moses (1997) mengemukakan "bahwa perusahaan-perusahaan yang lebih besar memiliki dorongan yang lebih besar untuk melakukan perataan laba (salah satu bentuk manajemen laba) dibandingkan dengan perusahaan kecil, karena memiliki biaya politik lebih besar. Biaya politik muncul dikarenakan profitabilitas perusahaan yang tinggi sehingga dapat menarik perhatian media dan konsumen.

Manajemen pada perusahaan yang berskala besar dan industri strategis yang melibatkan hajat hidup orang banyak memiliki biaya politis yang besar cenderung untuk melakukan manajemen laba dengan cara menurunkan laba. (Scoot, 2003 dalam Luhgiatno, 2008). Karena biaya politik yang tinggi dapat menarik perhatian media dan konsumen (Watts dan Zimmerman, 1986 dalam Halim,dkk 2005). Berdasarkan penjelasan di atas, maka hipotesisnya dapat dirumuskan sebagai berikut:

H7: Ukuran perusahaan berpengaruh positif terhadap manajemen laba. 


\section{Metodologi Penelitian}

\section{Populasi dan Teknik Pengambilan Sampel}

Populasi dalam penelitian ini meliputi semua perusahaan manufaktur yang sahamnya terdaftar di Bursa Efek Indonesia (BEI). Sedangkan untuk penentuan sampelnya didasarkan pada metode purposive sampling dengan kriteria sebagai berikut :

1. Perusahaan manufaktur yang listed di Bursa Efek Indonesia selama tiga (3) tahun berturut - turut dalam kurun waktu 2009 - 2011

2. Perusahaan telah mempublikasikan laporan keuangan dan laporan tahunan secara berturut - turut selama periode 2009-2011.

3. Perusahaan mempunyai data lengkap secara berturut-turut periode 2009 $-2011$.

Setelah dilakukan seleksi pemilihan sampel sesuai kriteria yang telah ditentukan maka diperoleh 31 perusahaan setiap tahunnya yang memenuhi kriteria sampel, sehingga sampel dalam penelitian ini sebanyak 93 perusahaan. Proses pemeilihan sampel disajikan pada tabel 2 berikut:

Tabel 2 : Proses Pemilihan Sampel Penelitian

\begin{tabular}{|l|l|l|}
\hline No & \multicolumn{1}{|c|}{ Keterangan } & Jumlah \\
\hline $\mathbf{1}$ & Perusahaan yang terdaftar di BEI tahun 2009, 2010 dan 2011 & $\mathbf{1 6 0}$ \\
\hline $\mathbf{2}$ & Perusahaan yang tidak terdaftar di BEI tahun 2009,2010, dan 2011 & $(\mathbf{9})$ \\
\hline $\mathbf{3}$ & $\begin{array}{l}\text { Perusahaan yang tidak memiliki kelengkapan data selama tahun } \\
\text { 2009-2011 }\end{array}$ & $\mathbf{( 1 0 6 )}$ \\
\hline & Jumlah Perusahaan Sampel & $\mathbf{3 1}$ \\
\hline
\end{tabular}




\section{Jenis dan Sumber Data}

Data yang digunakan dalam penelitian ini merupakan data sekunder berupa laporan keuangan dan laporan tahunan perusahaan manufaktur yang terdaftar di BEI dalam kurun waktu 2009 - 2011. Data diperoleh dari Pojok BEI Fakultas Ekonomi Universitas Islam Indonesia.

\section{Definisi Operasional dan Pengukuran Variabel}

\section{Variabel dependen}

Variabel dependen dalam penelitian ini adalah earnings management yang diukur dengan proxy discretionary accruals (DA). Adapun langkah-langkah untuk menghitung discretionary accruals adalah:

a. Mengukur total accrual dengan menggunakan model Jones yang dimodifikasi dengan rumus:

Total Accrual (TAC) = laba bersih setelah pajak (net income) arus kas operasi (cash flow from operating)

b. Menghitung nilai accruals yang diestimasi dengan persamaan regresi OLS (Ordinary Least Square):

TACt $/ A t-1=\alpha 1(1 / A t-1)+\alpha 2(\Delta R E V t / A t-1)+\alpha 3(P P E t / A t-)+e$ Dimana :

TACt : total accruals perusahaan i pada periode $\mathrm{t}$

At-1 : total aset untuk sampel perusahaan i pada akhit tahun $t-1$ REVt : perubahan pendapatan perusahaan i dari tahun t-1 ke tahun $\mathrm{t}$

RECt : perubahan piutang perusahaan i dari tahun $\mathrm{t}-1 \mathrm{ke}$ tahun $\mathrm{t}$ PPEt: aktiva tetap (gross property plant and equipment) perusahaan tahun $t$ 
c. Menghitung nondiscretionary accruals model (NDA) adalah sebagai berikut:

NDAt $=\alpha 1(1 /$ At-1 $)+\alpha 2((\Delta R E V t-\Delta R E C t) /$ At-1 $)+\alpha 3($ PPEt $/$ At -

1) $+\mathbf{e}$

Dimana

NDAt : nondiscretionary accruals pada tahun $\mathrm{t}$

a $\quad$ :fitted coefficient yang diperoleh dari hasil regresi pada perhitungan total accruals

d. Menghitung discretionary accruals

\section{DAit $=($ TACt $/$ At-1 $)-$ NDAt}

Dimana :

DAit : discretionary accruals perusahaan i pada periode t

\section{Variabel Independen}

Variabel independen dalam penelitian ini adalah (1) mekanisme corporate governance yang diukur dengan menggunakan 4 variabel, yaitu konsentrasi kepemilikan, struktur dewan komisaris independen, komite audit, dan reputasi auditor, (2) bonus plans, (3)debt-covenant dan (4) firm size.

\section{Konsentrasi Kepemilikan Saham}

Kepemilikan saham terkonsentasi (KS) adalah suatu kondisi di mana sebagian besar saham dimiliki oleh sebagian kecil individu/kelompok, sehingga individu atau kelompok tersebut memiliki jumlah saham relatif dominan dibandingkan dengan pemegang saham lainnya. Konsentrasi kepemilikan saham pada penelitian ini diproksi dengan jumlah kepemilikan terbesar oleh individu. 
Marfuah \& Himawan Yogatama, Pengaruh Mekanisme

\section{Struktur Dewan Komisaris Independen}

Pengukuran struktur dewan komisaris independen dilakukan dengan cara menghitung proporsi antara total dewan komisaris independen dengan total anggota dewan komisaris. Informasi mengenai jumlah dewan komisaris independen diperoleh dari laporan tahunan masing-masing perusahaan.

\section{Komite Audit}

Pengukuran variabel komite audit adalah dengan menghitung jumlah anggota komite audit perusahaan sampel. Data mengenai jumlah komite audit diperoleh dari laporan keuangan pada bagian catatan atas laporan keuangan maupun laporan tahunan perusahaan.

\section{Reputasi Auditor}

Reputasi auditor diukur dengan menggunakan variabel dummy. Jika auditor termasuk KAP Big 4 maka diberi skor 1 dan jika auditor tidak termasuk KAP Non Big 4 maka diberi skor 0.

KAP Indonesia yang teraffiliasi dengan KAP BIG 4 antara lain :

1. KAP Purwantono, Sarwoko, Sandjaja teraffiliasi dengan KAP Ernst \& Young.

2. KAP Osman Bing Satrio teraffiliasi dengan KAP Deloitte Touche Tohmatsu.

3. KAP Sidharta, Widjaja teraffiliasi dengan KAP KPMG

4. KAP Haryanto Sahari teraffiliasi dengan KAP Pricewaterhouse Coopers 


\section{Bonus Plans}

Penentuan ada tidaknya pemberian Bonus Plans yang diterima oleh manajemen dapat diperoleh informasi yang berasal dari laporan keuangan perusahaan. Bonus Plans diukur dengan menggunakan variable dummy dengan ketentuan nilai 1 untuk perusahaan manufaktur yang memberikan kompensasi bonus pada tahun tertentu sedangkan nilai 0 untuk perusahaan manufaktur yang tidak memberikan kompensasi bonus pada tahun tertentu.

\section{Debt Covenant}

Dalam penelitian ini, variabel debt covenant diukur dengan debt to equity ratio yang merupakan hasil pembagian total utang dengan total ekuitas. Menurut Scott (2003) dalam Luhgiatno (2008), Kontrak hutang jangka panjang (debt covenant) merupakan perjanjian untuk melindungi pemberi pinjaman (lender atau kreditor) dari tindakan manajer terhadap kepentingan kreditor, seperti deviden yang berlebihan, pinjaman tambahan, atau membiarkan model kerja dan kekayaan pemilik berada di bawah tingkat yang telah ditentukan, yang mana semuanya menurunkan keamanan (atau menaikkan risiko) bagi kreditur yang telah ada. Semakin tinggi DER menunjukkan komposisi total hutang (jangka pendek dan jangka panjang) semakin besar dibanding dengan total modal sendiri, sehingga berdampak semakin besar beban perusahaan terhadap pihak luar (kreditur). Perusahaan dengan rasio debt to equity yang tinggi akan mengalami kesulitan dalam memperoleh dana tambahan dari pihak kreditor bahkan perusahaan terancam melanggar perjarijian utang. (Watts dan Zimmerman, 1986 dalam Halim ,dkk 2005), 


\section{Ukuran Perusahaan (Size)}

Pengukuran variabel ukuran perusahaan (firm size) dalam penelitian ini menggunakan nilai Ln Total Asset:-

\section{Metode Analisis Data}

Metode analisis yang digunakan untuk menguji hipotesis penelitiin adalah analisis regresi linier berganda dengan menggunakan software SPSS 15. Model regresi yang digunakan untuk menguji hipotesis yang telah dirumuskan dalam penelitian ini adalah:

$\mathrm{DA}=\beta 0+\beta 1$ Konsentrasi $+\beta 2$ Komisaris $+\beta 3$ Komite $+\beta 4$ Reputasi + $\beta 5$ Bonus $+\mathrm{B} 6 \mathrm{DER}+\beta 7 \mathrm{SIZE}+\varepsilon$

\section{Keterangan:}

DA : nilai discretionary accrual yang dihitung menggunakan model Jones

Konsentrasi : konsentrasi kepemilikan saham

Komisaris : persentase komisaris independen terhadap total komisaris

Komite : Jumlah komite audit

Reputasi : Reputasi auditor diukur dengan ukuran KAP yang diukur dengan dummy, dimana:

$1=$ termasuk $\mathrm{KAP}$ big 4

$0=$ tidak termasuk KAP big 4

Bonus : Bonus Plans pada tahun t yang diukur dengan dummy, dimana:

1 = terdapat pemberian Bonus Plans kepada manajemen $0=$ tidak terdapat pemberian Bonus Plans kepada manajemen 
DER : Debt to Equity ratio sebagai pengukur variabel debt covenant

SIZE : ukuran perusahaan

$\varepsilon \quad$ : error

Adapun kriteria pengujian hipotesis adalah: $\mathrm{H} 0$ ditolak, jika p-value atau (sig-t) $<\alpha=5 \%$ dan arah/tanda koefisien regresi sesuai dengan yang diprediksi.

\section{Analisis Data Dan Pembahasan}

Pengujian hipotesis dilakukan dengan menggunakan analisis regresi berganda. Sebelum dilakukan uji hipotesis, dilakukan uji asumsi klasik yang terdiri uji normalitas, uji multikolinieritas, uji heteroskedastisitas dan uji autokorelasi. Berdasarkan hasil pengujian menunjukkan bahwa data berdistribusi normal dan model regresi tidak ada gejala multikolinearitas, heterokedastisitas dan autokorelasi. Hasil penguj disajikan pada table 3 berikut ini:

\section{Tabel 4.5}

\section{Hasil Analisis Regresi Linier Berganda}

\begin{tabular}{|l|c|l|c|c|l|}
\hline \multicolumn{1}{|c|}{ Variable } & $\begin{array}{c}\text { Koefisien } \\
(\mathbf{B})\end{array}$ & \multicolumn{1}{|c|}{ t } & Sig. t & Prediksi & Kesimpulan \\
\hline Konstanta & .544 & .925 & .357 & & \\
\hline Konsentrasi & -.006 & - & .043 & - & H1 didukung \\
\hline Komisaris & .421 & 1.834 & .070 & - & H2 didukung \\
\hline Komite & -.081 & - & .309 & - & $\begin{array}{l}\text { H3 tidak } \\
\text { didukung }\end{array}$ \\
\hline Reputasi & .203 & 3.804 & .000 & - & H4 didukung \\
\hline Bonus & .104 & 2.274 & .025 & + & H5 didukung \\
\hline DER & -.011 & -.795 & .429 & + & $\begin{array}{l}\text { H6 tidak } \\
\text { didukung }\end{array}$ \\
\hline
\end{tabular}




\begin{tabular}{|l|l|l|l|l|l|l|}
\hline Size & -.023 & - & .254 & - & $\begin{array}{l}\text { H7 } \\
\text { didukung }\end{array}$ \\
\hline
\end{tabular}

Berdasarkan table di atas, maka model persamaan regresi adalah sebagai berikut :

DA $=0,544-0,006$ Konsentrasi + 0,421Komisaris $-0,081$ Komite + 0,203Reputasi + 0,104Bonus - 0,011DER - 0,023Size +e

Hasil uji $\mathrm{F}$ menunjukkan bahwa $\mathrm{F}$ statistic sebesar 5.858 dengan tingkat signifikansi F 0.000 . Dengan demikian bisa disimpulkan bahwa model regresi lolos uji kelayakan model. Nilai Adjusted $R^{2}$ sebesar 0,270. Hal ini mengindikasikan bahwa besarnya variasi variabel independent dalam mempengaruhi variable dependen adalah sebesar $27 \%$ dan sisanya sebesar $73 \%$ dipengaruhi oleh faktor-faktor lain yang tidak dimasukkan dalam model regresi.

Adapun pembahasan hasil penelitian dijelaskan untuk setiap pengujian hipotesis berikut:

\section{Pengaruh Konsentrasi Kepemilikan Saham Terhadap Manajemen}

\section{Laba}

Dari hasil analisis data diperoleh besarnya koefisien regresi $\beta_{1}$ yaitu $-0,006$ dengan nilai sig-t sebesar 0,043 sehingga dapat disimpulkan 'bahwa hipotesis 1 yang menyatakan bahwa konsentrasi kepemilikan berpengaruh negative terhadap manajemen laba didukung bukti. Hasil penelitian ini bermakna bahwa konsentrasi kepemilikan saham dapat menjadi mekanisme corporate governance dalam rangka pengendalian terhadap tindakan manjemen laba di perusahaan. Kehadiran pemegang saham pengendali atau mayoritas dapat membatasi perilaku opotunis 
manajemen, manajemen laba. Konsentrasi kepemilikan dapat menjadi mekanisme internal pendisiplinan manajemen, sebagai salah satu mekanisme yang dapat digunakan untuk meningkatkan efektivitas monitoring, karena dengan kepemilikan yang besar menjadikan pemegang saham memiliki akses informasi yang cukup signifikan untuk mengimbangi keuntungan informasional yang dimiliki manajemen. Jika ini dapat diwujudkan maka tindakan moral hazard manajemen berupa manajemen laba dapat dikurangi (Hubert dan Langhe, 2002).

Hasil ini sesuai dengan temuan Palestin (2006) yang menemukan bahwa konsentrasi kepemilikan saham berpengaruh negative terhadap manajemen laba. Demikian pula dengan temuan La Porta dan Silanez (1999) yang menyatakan bahwa pemegang saham yang terkonsentrasi dapat mengendalikan perusahaan melalui voting power atau representasi mereka di manajemen sehingga hak-hak mereka terlindungi.

\section{Pengaruh Struktur Dewan Komisaris Terhadap Manajemen Laba}

Dari hasil analisis data diperoleh besarnya koefisien regresi $\beta_{2}$ yaitu 0,421 dengan nilai sig-t sebesar 0,070 sehingga hipotesis 2 yang menyatakan bahwa komisaris independen berpengaruh negative terhadap manajeman laba tidak didukung. Hasil penelitian ini mengindikasikan bahwa dewan komisaris independen tidak memiliki kekuatan untuk mempengaruhi keputusan dewan komisaris. Peranan dewan komisaris tidak dapat meningkatkan kualitas laba dengan membatasi tingkat manajemen laba melalui fungsi monitoring atas pelaporan keuangan. $\mathrm{Hal}$ ini dapat dijelaskan bahwa penempatan dan penambahan dewan komisaris independen dimungkinkan hanya sekedar untuk memenuhi ketentuan formalitas belaka, sementara pemegang saham mayoritas masih 
ṁemegang peranan penting sehingga kinerja dari komisaris independen $\left.\right|_{1}$ idaklah terlalu efektif dalam mengendalikan tindakan manajemen laba.

Hasil penelitian ini sesuai dengan temuan Boediono (2005) yang menyatakan bahwa kuatnya pengendali pendiri perusahaan dan kepemilikan saham mayotitas menjadikan komisaris independen tidak independen sehingga fungsi pengawasan yang seharusnya dilakukan oleh anggota dewan komisaris independen menjadi tidak efektif.

\section{Pengaruh Komite Audit Terhadap Manajemen Laba}

Dari hasil analisis data diperoleh besarnya koefisien regresi $\beta_{3}$ yaitu -0,081 dengan nilai sig-t sebesar 0,309 sehingga dapat disimpulkan bahwa hipotesis 3 yang menyatakan bahwa Komite Audit tidak berpengaruh negatif signifikan terhadap manajemen laba tidak didukung. Hasil penelitian ini mengindikasikan bahwa komite audit yang telah dibentuk oleh perusahaan tidak menjalankan fungsi dan peranannya secara efektif sehingga komite audit tidak mampu mengendalikan tindakan manajemen laba. Menurut Sommer (1977) dalam Khomsiyah (2005), alasan lain yang mendukung hasil penelitian ini adalah peraturan ¿Bapepam belum menjelaskan karakteristik apa sajakah yang harus 'dimiliki oleh seseorang agar dapat dinyatakan memiliki financial literacy. Hasil penelitian ini sesuai dengan temuan yang dilakukan Pamudji dan Trihartati (2010) yang tidak menemukan pengaruh negative komite audit terhadap manajemen laba.

\section{Pengaruh Reputasi Auditor Terhadap Manajemen Laba}

Dari hasil analisis data di atas, diketahui besarnya $\beta_{4}$ adalah 0,203 'dengan nilai sig- $t$ sebesar 0,000 , artinya reputasi auditor berpengaruh 
positif signifikan terhadap manajemen laba. Temuan ini berlawanan dengan hipotesis 4 yang menyatakan bahwa reputasi auditor berpengaruh negative terhadap manajemen laba. Hal ini mengindikasikan bahwa semakin baik reputasi auditor tidak dapat mengurangi praktek manajemen laba yang terjadi pada perusahaan klien, sebaliknya semakin baik reputasi auditor justru meningkatkan kemungkinan terjadinya manajemen laba pada perusahaan. Hal ini menggambarkan bahwa audit oleh KAP besar atau KAP yang memiliki pangsa pasar besar belum mampu menjadi jaminan memberikan kualitas audit yang lebih baik daripa KAP kecil. Dengan demikian bisa dijelaskan bahwa hasil audit yang dilakukan oleh auditor Big 4 tidak dapat membatasi praktek manajemen laba serta membantu menjaga dan meningkatkan kepercayaan masyarakat umum terhadap laporan keuangan.

\section{Pengaruh Bonus Plans Terhadap Manajemen Laba}

Dari hasil analisis data diketahui besarnya koefisien regresi $\beta_{5}$ yaitu 0,104 dengan nilai sig-t sebesar 0,025, sehingga dapat disimpulkan bahwa hipotesis 5 yang menyatakan bahwa bonus plans berpengaruh positif terhadap manajemen laba didukung bukti. Hal ini mengindikasikan bahwa keberadaan bonus plans dalam perusahaan akan mendorong manajemen melakukan manajemen laba. Temuan ini bisa dijelaskan dengan bonus plan hypothesis yang menyatakan bahwa manajer perusahaan dengan rencana bonus lebih menyukai metode akuntansi yang meningkatkan laba periode berjalan. Pilihan tersebut diharapkan dapat meningkatkan nilai sekarang bonus yang akan diterima seandainya komite kompensasi dari Dewan Direktur tidak menyesuaikan dengan metode yang dipilih. Jika perusahaan memiliki kompensasi (bonus scheme), maka manajer akan cenderung melakukan tindakan yang mengatur laba bersih 
untuk dapat memaksimalkan bonus yang mereka terima. Hasil penelitian ini sesuai dengan temuan Palestin (2006) yang juga menemukan bahwa bonus plans berpengaruh positif terhadap manajemen laba.

\section{Pengaruh Debt Covenant Terhadap Manajemen Laba}

Dari hasil analisis data diperoleh besarnya koefisien regresi $\beta_{6}$ yaitu $-0,011$ dengan nilai sig-t sebesar 0,429 , sehingga hipotesis 6 yang menyatakan bahwa debt covenant berpengaruh positif terhadap manajemen laba tidak didukung. Hasil penelitian ini mengindikasikan bahwa pada perusahaan yang mendekati pelanggaran perjanjian utang tidak ada kecenderungan bagi manajer perusahaan untuk melakukan manajemen laba dengan memilih prosedur akuntansi yang memindahkan laba yang dilaporkan dari perioda masa datang ke periode saat ini.

Dengan demikian penelitian ini tidak mendukung temuan Nurul dan Baridwan (2005) yang menyimpulkan bahwa semakin tinggi debt to equity ratio, maka manajer cenderung mempengaruhi angka-angka akuntansi pada laporan keuangan.

\section{Pengaruh Ukuran Perusahaan Terhadap Manajemen Laba}

Berdasarkan analisis data diperoleh besarnya koefisien regresi $\beta_{7}$ yaitu $-0,203$ dengan nilai sig-t sebesar 0,254 sehingga dapat disimpulkan bahwa hipotesis 7 yang menyatakan bahwa ukuran perusahaan berpengaruh positif terhadap manajemen laba tidak didukung. Hasil penelitian ini tidak sejalan dengan temuan Scoot (2003 dalam Luhgiatno (2008) yang menyatakan bahwa manajemen pada perusahaan yang berskala besar dan industri strategis yang melibatkan hajat hidup orang 
banyak memiliki biaya politis yang besar cenderung untuk melakukan manajemen laba dengan cara menurunkan laba.

Hasil penelitian ini mengindikasikan bahwa perusahaanperusahaan besar yang terdaftar di BEI kurang memiliki dorongan untuk melakukan manajemen laba dibandingkan perusahaan-perusahaan kecil, karena perusahaan besar dipandang lebih kritis oleh pemegang saham dan pihak luar. Perusahaan besar memiliki basis investor yang lebih besar sehingga mendapat tekanan yang lebih kuat untuk menyajikan pelaporan keuangan yang kredible.

\section{Penutup}

\section{Kesimpulan}

Tujuan penelitian ini adalah untuk menguji pengaruh mekanisme corporate governance, bonus plans, debt covenant dan ukuran perusahaan terhadap manajemen laba. Mekanisme corporate governance dalam penelitian ini diukur dengan menggunakan empat variable yaitu konsentrasi kepemilikan, komisaris independen, komite audit dan reputasi auditor. Berdasarkan hasil analisis regresi berganda disimpulkan sebagai berikut:

1. Kedua variable corporate governance, yaitu konsentrasi kepemilikan dan reputasi auditor seperti yang diprediksi berpengaruh negative signifikan terhadap manajemen laba. Hal ini mengindikasikan bahwa semakin tinggi tingkat konsentrasi kepemilikan dan reputasi auditor, maka tindakan manajemen laba akan semakin menurun. Sementara pengujian terhadap variable komite audit dan komisaris independen menemukan hasil yang tidak sesuai dengan prediksi sebelumnya. 
Komite audit mempunyai pengaruh positif signifikan terhadap manajemen laba, sedangkan komisaris independen tidak mempunyai pengaruh negatif signifikan terhadap manajemen laba.

2. Hasil pengujian dari tiga variable lainnya, yaitu bonus plans, debt covenant dan ukuran perusahaan menunjukkan bahwa hanya variable bonus plans yang mempunyai pengaruh positif signifikan terhadrip manajemen laba. Hal ini mengindikasikan bahwa manajemen laba cenderung terjadi pada perusahaan yang mempunyai skema bonus, karena manajer cenderung melakukan tindakan yang inengatur laba bersih untuk dapat memaksimalkan bonus yang mereka terima.

\section{Keterbatasan Penelitian}

Dalam penelitian ini terdapat beberapa keterbatasan yang kemungkinan dapat mempengaruhi hasil penelitian, antara lain:

1. Penelitian ini hanya menggunakan perusahaan manufaktur sebagai obyek penelitian

2. Periode penelitian ini hanya tiga tahun, yaitu tahun 2009, 2010 dan 2011.

3. Penelitian ini belum menganalisis secara detail karakteristikkarakteristik corporate governance.

\section{Saran untuk Penelitian Berikutnya}

Dengan memperhatikan beberapa keterbatasan penelitian yang telah disampaikan, maka dapat diberikan saran-saran untuk penelitian selanjutnya, yaitu sebagai berikut:

1. Peneliti selanjutnya disarankan menambah sampel penelitian dengan periode yang berbeda, atau jenis indiustri yang lain sehingga 
diharapkan jumlah data emiten dengan komposisi dewan komisaris yang dominan lebih banyak.

2. Untuk penelitian selanjutnya disarankan untuk menambah periode penelitian sehingga dapat menggeneralisasikan hasil penelitian.

3. Penelitian selanjutnya diharapkan dapat menambah atau menggunakan karakateristik corporate governance yang lain seperti karakteristik komposisi dewan, diantaranya kompetensi dewan komisaris dan atau tingkat kesibukan dewan komisaris atau proxy kegagalan audit.

\section{Daftar Pustaka}

Babic, Verica. 2001. The Key Aspects of the Corporate Governance Restructuring in the Transition Process". Ekonomist, Vol.33.No.2.

Beneish, M.D. 2001. Earnings Management. A Perspective Management Finance, vol.27. Number 12.

Boediono, Gideon SB. 2005. “Kualitas Laba: Studi Pengaruh Mekanisme Corporate Governance dan Dampak Manajemen Laba dengan Menggunakan Analisis Jalur". Simposium Nasional Akuntansi VIII.

Chen, J (2001). Ownership Structure as Corporate Governance Mechanism: Evidance from Chinese Listed Companies. Economic of Planning 34, pg 53-72.

Dallas, George .2004. Governance and Risk. Analytical Hand books for Investors, Managers, Directors and Stakeholders, p.21. Standard and Poor. Governance Services, MC. Graw Hill. New York.

Halim, Julia, Carmel Meiden, Rudolf Lumban Tobing. 2005. Pengaruh Manajemen Laba pada Tingkat Pengungkapan Laporan Keuangan pada Perusahaan Manufaktur yang termasuk pada LQ-45. SNA VIII Solo. Ikatan Akuntan Indonesia.

Hamongan Siallagan dan Mas'ud Machfoedz. 2006. Mekanisme Corporate Governace, Kualitas Laba dan Nilai Perusahaan, Simposium Nasional Akuntansi $I X$, Padang.

Hubert Ooghe and. Tine De Langhe. 2002. The Anglo-American Versus The Continental European Corporate Governance Model: Empirical Evidance of Board Composition in Belgium. Europen Business Review, volume 14, number 6-2002-pp.437-449. 
La Porta R,.F. and Lopez-De Silanez. 1999. Corporate Ownership around the word. Journal of Finance 54, 471-518.

Luhgiatno. 2008."Mencegah Tindakan Manajemen Laba dengan Mekanisme Corporate Governance". Semarang.

Marrakchi S., Chtourou. Corporate Governance and Earning Management . 2001. Social Science Research Network (SSRN). http://paper.ssrn.com/abstract $=275053$

Moses, Douglas O, 1997, Income Smooting and Incentives: Empirical Using Accounting Changes, The Accounting Review, Vol.LXII,No.2, April,pp. 259-377).

Musnadi, Said. 2006. Kajian tentang Struktur Kepemilikan Terkonsentrasi,Tipe Kepemilikan dan Tipe Pengendalian sebagai Mekanisme Corporate Governance, serta Dampaknya terhadap Kinerja Keuangan Perusahaan. Disertasi. Universitas Padjadjaran Bandung.

Nasution, Marihot dan Doddy Setiawan. 2007. Pengaruh Corporate Governance Terhadap Manajemen Laba di Industri Perbankan Indonesia. Makalah disampaikan dalam Simposium Nasicnal Akuntansi X di Makassar, 26-28.

Nuryaman, 2005. Pengaruh Konsentrasi Kepemilikan, Ukuran Perusahaan dan Mekanisme Corporate Governance Terhadap Manajemen Laba. Jurnal Universitas Widyatama (Utama) Bandung.

Scott, William R., 2003, Financial Accounting Theory, Third Edition, University of Waterloo.

Veronica N.P Siregar, Sylvia dan Siddharta Utama. 2005. Pengaruh Struktur Kepemilikan, Ukuran Perusahaan, dan Praktik Corporate Governance terhadap Pengelolaan Laba. Simpsium Nasional Akuntansi VIII. Ikatan Akuntan Indonesia.

Watts, Ross L. and Jerold L. Zimmerman, 1986, Positive Accounting Theory, Prentice-Hall Inc., Englewood Cliffs, New Jersey.

Wedari, Linda Kusumaning. 2004 . Analisis Pengaruh Proporsi Dewan Komisaris dan Keberadaan Komite Audit terhadap Aktivitas Manajamen Laba . Simposium Nasional Akuntansi 7.

Widyaningdyah , Agnes Utari (2001), "Analisis Faktor-Faktor Yang Berpengaruh Terhadap Earnings Management Pada Perusahaan Go Public Di Indonesia",Jurnal Akuntansi \& Keuangan, November Vol. 3 No. 2. 
